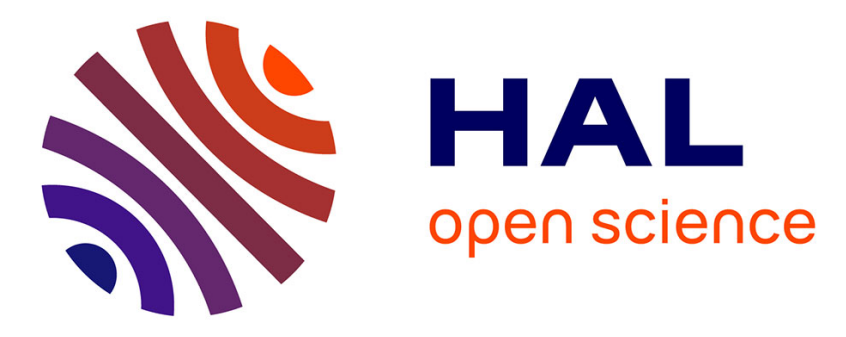

\title{
Metabolic Fate of 2,4-Dichlorophenol and Related Plant Residues in Rats
}

Sophie Lorber, Sabrina Despoux, Emilien L. Jamin, Cécile Canlet, Jean Pierre J. P. Cravedi, Francois Laurent

\section{- To cite this version:}

Sophie Lorber, Sabrina Despoux, Emilien L. Jamin, Cécile Canlet, Jean Pierre J. P. Cravedi, et al.. Metabolic Fate of 2,4-Dichlorophenol and Related Plant Residues in Rats. Journal of Agricultural and Food Chemistry, 2012, 60 (7), pp.1728-1736. 10.1021/jf203666k . hal-01137073

\section{HAL Id: hal-01137073 https://hal.science/hal-01137073}

Submitted on 8 Mar 2017

HAL is a multi-disciplinary open access archive for the deposit and dissemination of scientific research documents, whether they are published or not. The documents may come from teaching and research institutions in France or abroad, or from public or private research centers.
L'archive ouverte pluridisciplinaire HAL, est destinée au dépôt et à la diffusion de documents scientifiques de niveau recherche, publiés ou non, émanant des établissements d'enseignement et de recherche français ou étrangers, des laboratoires publics ou privés. 


\title{
Metabolic Fate of 2,4-Dichlorophenol and Related Plant Residues in Rats
}

\author{
and François Laurent ${ }^{\dagger, \S, \# ~}$ \\ ${ }^{\dagger}$ Université de Toulouse, INP, UPS, EcoLab, ENSAT, F-31000 Castanet Tolosan, France \\ ${ }^{\S}$ CNRS, EcoLab, F-31000 Castanet Tolosan, France \\ \#INRA, EcoLab, F-31000 Toulouse, France \\ ${ }^{\perp}$ INRA, UMR 1331, F-31000 Toulouse, France
}

Sophie Pascal-Lorber, ${ }^{*}, \dagger, \S, \#$ Sabrina Despoux, ${ }^{\dagger, \S, \#}$ Emilien L. Jamin, ${ }^{\perp}$ Cécile Canlet, ${ }^{\perp}$ Jean-Pierre Cravedi, ${ }^{\perp}$

ABSTRACT: This study compared the metabolic fate of $\left[{ }^{14} \mathrm{C}\right]-\mathrm{DCP},\left[{ }^{14} \mathrm{C}\right]$-residues from radish plants, and purified $\left[{ }^{14} \mathrm{C}\right]-$ DCP-(acetyl)glucose following oral administration in rats. A rapid excretion of radioactivity in urine occurred for $\left[{ }^{14} \mathrm{C}\right]-\mathrm{DCP}$, $\left[{ }^{14} \mathrm{C}\right]$-DCP-(acetyl)glucose, and soluble residues, 69,85 , and $69 \%$ within $48 \mathrm{~h}$, respectively. Radio-HPLC profiles of $0-24 \mathrm{~h}$ urine from rats fed $\left[{ }^{14} \mathrm{C}\right]$-DCP and $\left[{ }^{14} \mathrm{C}\right]$-DCP-(acetyl)glucose were close and qualitatively similar to those obtained from plant residues. No trace of native plant residues was detected under the study conditions. The structures of the two major peaks were identified by MS as the glucuronide and the sulfate conjugates of DCP. The characterization of a dehydrated glucuronide conjugate by MS and NMR of DCP was unusual. In contrast to soluble residues, bound residues were mainly excreted in feces, $90 \%$ within $48 \mathrm{~h}$, whereas total residues were eliminated in both urine and feces. For total residues, the radioactivity in feces was higher than expected from the percentage of soluble and bound residues in radish plants. This result highlighted that less absorption took place when residues were present in the plant matrix as compared to plant-free residues and DCP.

KEYWORDS: 2,4-dichlorophenol, Raphanus sativus, soluble residues, bound residues, rat, metabolism

\section{INTRODUCTION}

Chlorinated phenols are ubiquitous environmental pollutants listed as priority chemicals because of their persistence in the environment. Among these compounds, 2,4-dichlorophenol (DCP) is used in the manufacture of industrial and agricultural compounds, such as resins and antiseptics, and particularly in the production of the herbicide 2,4-dichlorophenoxyacetic acid (2,4-D). DCP arises from the photolysis of triclosan, an antibacterial compound, and was identified as a degradation metabolite of 2,4-D in aerated soils ${ }^{1}$ and of the insecticide ethyl prothiofos. $^{2}$ It is largely detected in the environment but is mainly found in wastewaters from chemical factories and in some sites of phenoxy acid herbicide application. Due to its $\log K_{\text {ow }}$ value of $3.11,3$ DCP can enter food chains leading to humans via edible plants, resulting in a potential food safety problem. Chlorophenols have been classified as possibly carcinogenic to humans by the International Agency for Research on Cancer. ${ }^{4}$ Oral exposure through food and water contaminated with chlorophenols is the main route of exposure for the general population. ${ }^{5}$ Exposure to DCP through contaminated food may result from the production of DCP through degradation and/or metabolism of herbicides such as 2,4-D. ${ }^{6}$ Limited data exist on the occurrence of DCP in food. ${ }^{7,8}$ However, food safety problems could increase in the future with the marketing of new engineered herbicide-resistant crops as they inactivate $2,4-\mathrm{D}$ to DCP.

Metabolism of xenobiotics in plants and animals shares common steps. A primary step consists of the introduction of functional groups by oxidation, reduction, or hydrolysis. A secondary step involves the conjugation of the resulting compounds with endogenous components (carbohydrates, glutathione, acetic acid) leading to more polar, water-soluble, and generally less toxic molecules. However, plants exhibit slight differences during conjugation processes. Glycosidation is the most encountered xenobiotic detoxification pathway, whereas conjugation to glucuronic acid is common in animals and rarely described in plants. ${ }^{10-12}$ In animals, conjugation with sulfate is a frequent reaction, but direct sulfation does not occur in plants even if some sulfate ester glucosides have been described in the metabolism of pesticides such as phendipham, ${ }^{13}$ profenofos, ${ }^{14}$ $2,4-\mathrm{D},{ }^{15}$ and DCP. ${ }^{16}$ Finally, as plants lack an efficient excretory system unlike animals, metabolites are then compartmented into vacuoles, excreted in intercellular spaces, and/or associated with cell walls as unextractable or bound residues. In plants or plant cells, DCP is primarily metabolized by conjugation with a diversity of C6 and C5 sugars such as glucose and apiose ${ }^{17}$ that can be subsequently conjugated to sulfate, acetate, malonate or other diacids. ${ }^{10}$ In mammals, DCP is mainly metabolized to glucuronide and other conjugates that were subsequently eliminated in urine. ${ }^{18}$ The plant-unique metabolites (metabolites in plants that have not been found in mammals) could be hydrolyzed in the gastrointestinal tract of animals. The released toxic aglycone part could become bioavailable. In addition, the structure of the sugar moiety has an influence on the absorption and the bioavailability of natural glycosides. ${ }^{19,20}$ The fate of

Received: September 9, 2011

Revised: January 24, 2012

Accepted: January 25, 2012

Published: January 25, 2012 
plant metabolites in animals is difficult to predict and needs a detailed characterization to evaluate their bioavailability and the risk they represent to humans. In a previous study, we have determined that in radish plants exposed during 3 weeks to $\left[{ }^{14} \mathrm{C}\right]-\mathrm{DCP}, \mathrm{ca} .60 \%$ of the radioactivity present in plant tissues was extractable in water/organic solvents mixtures, whereas approximately $40 \%$ of the total amount of residues remained as unextractable or bound residues. ${ }^{10}$ In the extract, the DCPacetyl-O-glucoside conjugate was the major metabolite, representing approximately $75 \%$ of the soluble fraction. Skidmore et al. $^{21}$ have investigated the bioavailability of specific phase II and phase III metabolites derived from plants. They found that phenol $\mathrm{O}$-glucose conjugates were stable at the $\mathrm{pH}$ values found in the mammalian gastrointestinal tract and in the presence of digestive enzymes. These results and prediction of permeability indicated that conjugates should be absorbed from the gut. Bound residues are mostly considered as weakly or even not bioavailable to animals because they are linked to nondigestible cell wall polymers such as lignin. However, studies on bioavailability remain scarce, and results are sometimes conflicting or difficult to interpret. ${ }^{21,22}$

The aim of the present study was to address to what extent DCP residues in edible plants were absorbed in mammals and to know whether the chemical form in which these residues exist may have a qualitative and/or quantitative impact on their distribution and metabolic pathways. To achieve this goal, we studied the metabolic fate of plant $\left[{ }^{14} \mathrm{C}\right]$-DCP-related residues in rats and compared the results with those obtained under similar experimental conditions with unchanged $\left[{ }^{14} \mathrm{C}\right]$-DCP and with $\left[{ }^{14} \mathrm{C}\right]$-DCP-(acetyl)glucose. Our study highlighted the presence of a novel metabolite: a dehydrated glucuronide conjugate of DCP. The influence of the vegetal matrix as well as the residual status on the absorption of the compounds was also determined.

\section{MATERIALS AND METHODS}

Chemicals. [U-phenyl- ${ }^{14} \mathrm{C}$ ]-2,4-Dichlorophenol (specific activity = $2.96 \mathrm{GBq} \mathrm{mmol}^{-1}$, radiochemical purity $>99 \%$ as determined by radio-RP-HPLC analysis) was purchased from ARC (St. Louis, MO). DCP (99\% pure), 2,4-dichlorophenoxyacetic acid, myoinositol, potassium phosphate, sodium ascorbate, sodium azide, sucrose, and thiamin were obtained from Sigma-Aldrich (Saint-Quentin Fallavier, France). Solvents used for extractions and radio-RP-HPLC analyses were provided by Scharlau Chemie S.A. (Barcelona, Spain). Unless otherwise specified, all other chemicals were of analytical grade.

Plant Material and Treatment. Radish seeds (Les Espaces Verts du Languedoc, Toulouse, France) were planted in quartz sand in $400 \mathrm{~mL}$ plastic pots and irrigated with quarter-strength Hoagland solution (Sigma H2395). Four-week-old plants were carefully removed from the sand. The roots were briefly rinsed under running water and then dipped in $500 \mu \mathrm{L}$ of $\left[{ }^{14} \mathrm{C}\right]$-DCP $(126 \mu \mathrm{g}, 1.11 \mathrm{MBq})$ dissolved in nutrient solution. After 3 weeks, edible roots were harvested, freezedried for $48 \mathrm{~h}$ to remove water, and stored at $-80{ }^{\circ} \mathrm{C}$ before use.

Extraction Procedures. Frozen plants were cut in slices and ground in a chilled mortar. An aliquot of the resulting powder was kept to measure the total radioactivity taken up by plants. Ground tissues were either directly used for rats as total residues or transferred in methanol/dichloromethane/water $(2: 1: 0.8, \mathrm{v} / \mathrm{v} / \mathrm{v})$, homogenized for $4 \mathrm{~h}$ in a vortex, and stored overnight at $-20{ }^{\circ} \mathrm{C}$. The resulting extract was then sonicated with an ultrasonic cell disrupter (Branson sonifier 450, Fischer Bioblock, Illkirch, France) for $5 \mathrm{~min}$ and centrifuged at $10000 \mathrm{~g}$ for $10 \mathrm{~min}$. The pellet was washed two times with the solvent mixture. The three supernatants, which contained the soluble (extractable) residues, were combined and evaporated under vacuum to remove organic solvents. The pellets, which consisted of the unextractable residues, were allowed to air-dry for $24 \mathrm{~h}$ at room temperature to remove organic solvents and then freeze-dried for $60 \mathrm{~h}$ to remove water. Pellets were further Soxhlet-extracted with ethanol/ benzene $(9: 1, \mathrm{v} / \mathrm{v})$ for $48 \mathrm{~h}$ to give the free cell wall fraction, ${ }^{23}$ which was stored under nitrogen in a desiccator until used. The following residual fractions were investigated: (1) total residues (corresponding to soluble and bound residues), (2) soluble fraction (corresponding to the radioactive material extractable in methanol/dichloromethane/ water), and (3) covalently bound residues (unextractable fraction).

Cell Culture $\left[{ }^{14} \mathrm{C}\right]-\mathrm{DCP}$ Application and Preparation of Cell Extracts. Cell cultures are a good tool to obtain large quantities of metabolites without the inherent difficulties of penetration and translocation through whole plants, and metabolites are easier to purify. In addition, they metabolize completely DCP to sugar conjugates. ${ }^{12}$ Tobacco cell suspension cultures (Nicotiana tabacum BY2) were grown in the dark at $25{ }^{\circ} \mathrm{C}$ in $1 \mathrm{~L}$ Erlenmeyer flasks containing $250 \mathrm{~mL}$ of Murashige and Skoog medium (Sigma M-5524) supplemented with vitamins and plant growth regulators: $\mathrm{KH}_{2} \mathrm{PO}_{4}\left(200 \mathrm{mg} \mathrm{L}{ }^{-1}\right)$, sucrose $\left(30 \mathrm{~g} \mathrm{~L}^{-1}\right)$, myoinositol $\left(100 \mathrm{mg} \mathrm{L}^{-1}\right)$, thiamin $\left(10 \mathrm{mg} \mathrm{L}^{-1}\right)$, and 2,4-D $\left(10^{-6} \mathrm{~mol} \mathrm{~L}^{-1}\right)$. The $\mathrm{pH}$ of the medium was adjusted to 5.8. Cells $(25 \mathrm{~mL})$ were transferred weekly into fresh sterile medium to maintain the culture in exponential growth. A $10000 \mu \mathrm{g}$ sample of unlabeled DCP and $3.33 \times 10^{5} \mathrm{~Bq}$ of $\left[{ }^{14} \mathrm{C}\right]$-DCP $(250 \mu \mathrm{L}$, dissolved in ethanol $)$ were added to the culture medium 5 days after its transfer into fresh medium. Incubation was ended $24 \mathrm{~h}$ after treatment. Cells were separated from the medium by centrifugation at $3000 \mathrm{~g}$ for $10 \mathrm{~min}$, and the pellet was washed two times with water. Cells were then sonicated for $15 \mathrm{~min}$ with an ultrasonic cell disrupter (Branson sonifier 450, Fischer Bioblock) and centrifuged at $10000 \mathrm{~g}$ for $10 \mathrm{~min}$. The supernatant was further purified by solid phase extraction on C18 cartridges (Supelco, Saint-Quentin Fallavier, France) and eluted with $80 \%$ methanol. Eluates, which contained all of the radioactivity, were dried under vacuum to remove methanol and stored at $-80{ }^{\circ} \mathrm{C}$. Medium was freeze-dried for $60 \mathrm{~h}$ to remove water, purified, and stored as described above.

Animal Experiments. After a 5 day adaptation period with free access to water and to a standard diet (groups I, II, and III) or a semisynthetic liquid diet (groups IV and V) (UAR 210; UAR, Villemoissonsur-Orge, France), and under a $12 \mathrm{~h}$ light/dark cycle, male rats (Wistar, 200-220 g, Iffa-Credo, l'Arbresle, France) were individually housed in stainless steel metabolic cages with free access to water. They were randomly divided into five groups (three rats per group).

Groups I, II, and III. Radiolabeled $\left[{ }^{14} \mathrm{C}\right]$-DCP (group I, $10 \mathrm{mg} \mathrm{kg}{ }^{-1}$, $740000 \mathrm{~Bq}$ per rat), the major cell metabolite (group II, $7 \mathrm{mg}$ corresponding to $523000 \mathrm{~Bq}$ per rat), and extractable residues from radish (group III, $68.2 \mu \mathrm{g}$ corresponding to $595350 \mathrm{~Bq}$ per rat) dissolved in deionized water were administrated orally as a single dose via a stomach tube device, a $1.0 \mathrm{~mL}$ plastic syringe fitted with $10 \mathrm{~cm}$ of Teflon tubing $(1 / 32$ in.). The radioactivity remaining in the syringe and tubing was measured to determine the amount of product actually administered.

Groups IV and V. During the 5 day adaptation period, rats were fed ground untreated radish mixed with the semisynthetic liquid diet. Rats were starved one night, then fed bound residues (group IV, $476 \mathrm{mg}$ corresponding to $383548 \mathrm{~Bq}$ per rat) or total residues (group V, $511 \mathrm{mg}$ corresponding to $487050 \mathrm{~Bq}$ per rat) incorporated into a small amount of the semisynthetic liquid diet. This route of administration was used because the specific activity of bound and total residues was too weak for a treatment by gavage.

Urine $\left(+100 \mu \mathrm{L}\right.$ of sodium ascorbate $15 \mathrm{mg} \mathrm{mL}^{-1}$ and $100 \mu \mathrm{L}$ of sodium azide $20 \mathrm{mg} \mathrm{mL}^{-1}$ ) and feces were collected after 24 and $48 \mathrm{~h}$. After $48 \mathrm{~h}$, rats were euthanized. Liver, kidneys, and the digestive tract including its content (from duodenum to rectum) were removed. Metabolic cages were washed with methanol, from which aliquots were taken to determine residual radioactivity. All samples were stored at $-20{ }^{\circ} \mathrm{C}$ when not used immediately.

Determination of Radioactivity. Radioactivity in urine, plant extractable residues, and all other liquid samples was determined by direct counting on a Packard scintillation analyzer (model Tricarb 2200CA, PerkinElmer Life and Analytical Sciences, Courtaboeuf, France) using a Packard Ultima Gold scintillation cocktail (PerkinElmer LAS). Radioactivity in rat tissues, feces, plant parts, and extraction pellets was 
measured by complete combustion of aliquots using a Packard Oxidizer 307 (PerkinElmer LAS) followed by ${ }^{14} \mathrm{CO}_{2}$ quantification on the scintillation counter (PerkinElmer LAS scintillation cocktail: Permafluor and Carbosorb, 10:7, v/v). The efficiency of the oxidizer was measured by combustion of ${ }^{14} \mathrm{C}$-standards, and the recoveries of radioactivity from samples were adjusted to allow for the efficiency of the instrument. The sample weight varied between 0.085 and $0.170 \mathrm{~g}$. Amounts of residues were calculated from the specific activity of DCP as equivalent (equiv) parent compound.

High-Performance Liquid Chromatography. Samples were analyzed on a Spectra-Physics P4000 apparatus (Les Ulis, France) equipped with a Rheodyne model 7125 injector (Rheodyne, Cotati, CA) connected for radioactivity detection to a Packard Flo-One $\beta$ A500 instrument (cell volume, $0.5 \mathrm{~mL}$; scintillation cocktail ratio, $2 \mathrm{~mL}$ scintillation liquid $\mathrm{mL}^{-1}$ HPLC effluent) (PerkinElmer LAS) using Flo-Scint II as scintillation cocktail (PerkinElmer LAS) to establish metabolic profiles or to a Gilson model FC-204 fraction collector set at 4 fractions $\min ^{-1}$ (Gilson Medical Electronics, Middleton, WI) for metabolite purification. An aliquot of each fraction was counted in a scintillation counter to monitor radioactivity. The fractions of each peak were combined and evaporated to dryness under vacuum. Each peak was then purified by solid phase extraction on C18 cartridges (Supelco) and eluted with increasing concentrations of methanol. Eluates from 40 to $60 \%$, depending on each peak, that contained the maximum of radioactivity were dried under vacuum and stored at $-20{ }^{\circ} \mathrm{C}$ until analysis by mass spectrometry (MS) or nuclear magnetic resonance spectroscopy ( ${ }^{1} \mathrm{H}$ NMR). The HPLC system consisted of a C18 Bischoff reverse-phase column (Prontosil Eurobond, Interchim, Montluçon, France) $(250 \times 4.6$ $\mathrm{mm}, 5 \mu \mathrm{m})$ coupled to a $\mathrm{C} 18$ guard precolumn $(10 \times 4.6 \mathrm{~mm}, 5$ $\mu \mathrm{m}$, Interchim). The column was equilibrated with $100 \%$ solvent $\mathrm{A}$ (water/acetonitrile/formic acid, 95:5:0.2, v/v/v). Elution conditions were performed as follows: a 30 min linear gradient leading to $100 \%$ solvent $B$ (water/acetonitrile/formic acid, 60:40:0.2, v/v/v) and then $100 \%$ solvent $\mathrm{B}$ for $15 \mathrm{~min}$. The flow rate was $1 \mathrm{~mL} \mathrm{~min}^{-1}$ at $30{ }^{\circ} \mathrm{C}$.

Mass Spectrometry. The structural characterization of metabolites (Table 1) was performed with an LCQ quadrupole ion trap mass

Table 1. MS Characteristics of Isolated Metabolites after HPLC Analysis and Identification by Mass Spectrometry

\begin{tabular}{|c|c|c|c|c|}
\hline isolated metabolite & $\begin{array}{l}t_{\mathrm{R}} \text { in } \\
\text { HPLC } \\
(\mathrm{min})\end{array}$ & $\begin{array}{c}\text { precursor ion } \\
{[\mathrm{M}-\mathrm{H}]^{-} \mathrm{m} / \mathrm{z}}\end{array}$ & $\begin{array}{c}\text { isotopic } \\
\text { composition }\end{array}$ & $\begin{array}{c}\text { main } \\
\text { fragment ions } \\
\mathrm{m} / \mathrm{z}\end{array}$ \\
\hline \multirow{2}{*}{$\begin{array}{l}\text { DCP-(acetyl) } \\
\text { glucose (tobacco } \\
\text { cells) }\end{array}$} & \multirow[t]{2}{*}{27.80} & 365 & ${ }^{35} \mathrm{Cl}_{2}$ & 161 \\
\hline & & 367 & ${ }^{35} \mathrm{Cl}_{1}+{ }^{37} \mathrm{Cl}_{1}$ & 163 \\
\hline \multirow{2}{*}{$\begin{array}{l}\text { DCP-glucuronide } \\
\text { (urine) }\end{array}$} & \multirow[t]{2}{*}{24.30} & 337 & ${ }^{35} \mathrm{Cl}_{2}$ & $175,161,113$ \\
\hline & & 339 & ${ }^{35} \mathrm{Cl}_{1}+{ }^{37} \mathrm{Cl}_{1}$ & $175,163,113$ \\
\hline \multirow{2}{*}{$\begin{array}{l}\text { DCP-sulfate } \\
\text { (urine) }\end{array}$} & \multirow[t]{2}{*}{28.30} & 241 & ${ }^{35} \mathrm{Cl}_{2}$ & 161 \\
\hline & & 243 & ${ }^{35} \mathrm{Cl}_{1}+{ }^{37} \mathrm{Cl}_{1}$ & 163,161 \\
\hline \multirow{2}{*}{$\begin{array}{l}\text { DCP-dehydrated } \\
\text { glucuronide } \\
\text { (urine) }\end{array}$} & \multirow[t]{2}{*}{31.40} & 319 & ${ }^{35} \mathrm{Cl}_{2}$ & 161,157 \\
\hline & & 321 & ${ }^{35} \mathrm{Cl}_{1}+{ }^{37} \mathrm{Cl}_{1}$ & 163,157 \\
\hline
\end{tabular}

analyzer (Thermo Scientific, Les Ulis, France) fitted with an electrospray ionization (ESI) source operating in the negative mode. Samples dissolved at $1 \mathrm{ng} \mu \mathrm{L}^{-1}$ in $\mathrm{MeOH} / \mathrm{H}_{2} \mathrm{O}$ (50:50, v/v) were introduced into the ionization source at a flow rate of $3 \mu \mathrm{L} \mathrm{min}$. Operating parameters for the production and transmission of ions produced by ESI were optimized for each metabolite: source voltage, from 3 to $4.7 \mathrm{kV}$; sheath gas $\left(\mathrm{N}_{2}\right)$, from 65 to $70 \mathrm{au}$; auxiliary gas $\left(\mathrm{N}_{2}\right)$, $0 \mathrm{au}$; capillary voltage, from -28 to $-11 \mathrm{~V}$; capillary temperature, from
175 to $200{ }^{\circ} \mathrm{C}$; and tube lens offset, from -20 to $15 \mathrm{~V}$. MS/MS parameters (isolation width, excitation voltage, and excitation time) were also optimized for each compound to obtain maximum structural information.

Nuclear Magnetic Resonance Spectroscopy. ${ }^{1} \mathrm{H}$ and twodimensional nuclear magnetic resonance (2D-NMR) spectra were acquired at $300 \mathrm{~K}$ using a Bruker Avance DRX-600 spectrometer (Bruker, Wissembourg, France) operating at $600.13 \mathrm{MHz}$ and equipped with a $5 \mathrm{~mm} \mathrm{H}, \mathrm{C}, \mathrm{N}$ inverse triple-resonance cryoprobe attached to a Cryoplatform (the preamplifier cooling unit). Sample was dissolved in $600 \mu \mathrm{L}$ of deuterated methanol $\left(\mathrm{CD}_{3} \mathrm{OD}\right)$.

A one-dimensional ${ }^{1} \mathrm{H}$ NMR spectrum was acquired using a standard pulse sequence for ${ }^{1} \mathrm{H}$ NMR; 1024 free induction decays (FIDs) were collected with a spectral width of $12 \mathrm{ppm}$ into $64 \mathrm{~K}$ data points. An exponential function equivalent to a line-broadening of $0.3 \mathrm{~Hz}$ was applied prior to Fourier transformation. A two-dimensional ${ }^{1} \mathrm{H}-{ }^{1} \mathrm{H}$ correlation spectroscopy (COSY) NMR spectrum was acquired under the following conditions: spectral width of $12 \mathrm{ppm}$ in both dimensions, $1 \mathrm{~K}$ data points in the $\mathrm{f} 2$ dimension, 512 increments in the $\mathrm{f} 1$ dimension, and 32 scans. The ${ }^{1} \mathrm{H}-{ }^{13} \mathrm{C}$ heteronuclear singlequantum correlation (HSQC) NMR spectrum was acquired using a standard echo/antiecho-TPPI gradient selection pulse sequence with the following parameters: spectral width of 12 and $180 \mathrm{ppm}$ for proton and carbon dimensions, respectively, $1 \mathrm{~K}$ data points in the $\mathrm{f} 2$ dimension, 256 increments in the $\mathrm{f} 1$ dimension, and 64 scans. The ${ }^{1} \mathrm{H}-{ }^{13} \mathrm{C}$ heteronuclear multiple-bond connectivity (HMBC) NMR spectrum optimized for long-range couplings was obtained with a $5 \mathrm{~s}$ relaxation delay, a spectral width of 12 or $220 \mathrm{ppm}$ for the proton and carbon dimensions, respectively, $1 \mathrm{~K}$ data points in the $\mathrm{f} 1$ dimension, 512 increments in the $\mathrm{f} 2$ dimension, and 128 scans.

Data Analysis. Results, expressed as micrograms of equivalent parent compound per gram, were always relative to DW. Amounts of urine metabolites of rats following administration of $\left[{ }^{14} \mathrm{C}\right]-\mathrm{DCP}$, $\left[{ }^{14} \mathrm{C}\right]$-DCP-(acetyl)glucose, $\left[{ }^{14} \mathrm{C}\right]$-soluble residues, and $\left[{ }^{14} \mathrm{C}\right]$-total residues were analyzed for statistical significance by a two-tailed Student's $t$ test $(p<0.05)$.

\section{RESULTS AND DISCUSSION}

Distribution of Radioactivity in Plants and Plant Cells. DCP was metabolized mainly to DCP-(acetyl)glucose in radish plants (Figure 1A). The major metabolite isolated from tobacco cell suspension cultures is shown in Figure 1B.

The doses of DCP and DCP-(acetyl)glucose administered to rats were approximately equimolar, $15.3 \mu \mathrm{mol}(2.5 \mathrm{mg})$ and $19.4 \mu \mathrm{mol}(7 \mathrm{mg})$ per animal, respectively. The specific activities of plant residues were weak due to a limited absorption of compounds by radish plants. The amounts of residues (soluble, $75 \mu \mathrm{g}$; total residues, $37 \mu \mathrm{g}$; bound residues, $52 \mu \mathrm{g}$ ) obtained from treated radish plants, which were administered to each rat, were lower than the quantity of DCP and DCP-(acetyl)glucose administered per animal. Bound residues were obtained after Soxhlet extraction of cell walls, which gives the free cell wall fraction. $^{24}$

Distribution of Radioactivity in Rats. Residual levels of radioactivity measured in excreta and tissues (liver, kidney) after oral administration to rats of $\left[{ }^{14} \mathrm{C}\right]$-DCP (group I), $\left[{ }^{14} \mathrm{C}\right]$ DCP-(acetyl)glucose (group II), $\left[{ }^{14} \mathrm{C}\right]$-soluble (group III), $\left[{ }^{14} \mathrm{C}\right]$-bound (group IV), and $\left[{ }^{14} \mathrm{C}\right]$-total residues (group V) from radish are summarized in Table 2. Total recoveries for the different experiments ranged from 73 to $92 \%$ of the administered radioactivity. Only small amounts of radioactivity were found in the analyzed tissues, including the digestive tract and its content (not shown). $\left[{ }^{14} \mathrm{C}\right]-\mathrm{DCP},\left[{ }^{14} \mathrm{C}\right]-\mathrm{DCP}$-soluble residues, and $\left[{ }^{14} \mathrm{C}\right]$-DCP-(acetyl)glucose were absorbed and eliminated in urine within $24 \mathrm{~h}$. In all groups, the levels of residues in the liver and kidney were very low. This is in accordance with the 


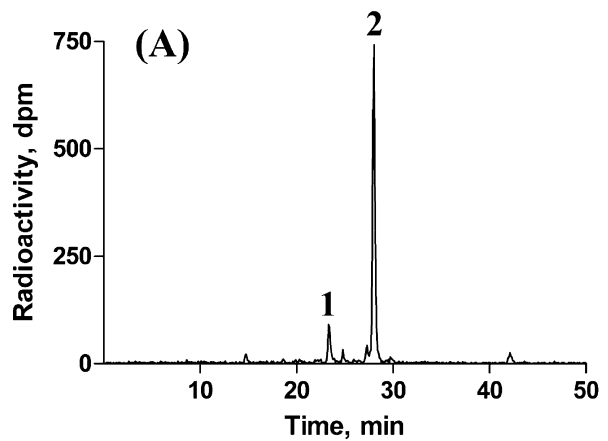

(1)

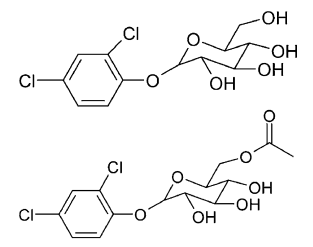

(2)

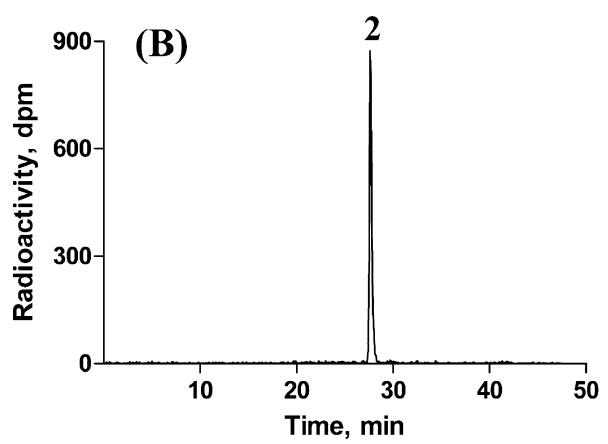

Figure 1. Typical radio-HPLC profiles of (A) soluble residues obtained from extracts of edible roots of radish and (B) DCP-(acetyl)glucose isolated from tobacco cell suspension cultures.

Table 2. Elimination of Radioactivity in $0-24$ and $0-48 \mathrm{~h}$ Urine by Rats after Oral Administration of [ $\left.{ }^{14} \mathrm{C}\right]-\mathrm{DCP}$ (Group I), $\left[{ }^{14} \mathrm{C}\right]-\mathrm{DCP}\left(\right.$ acetyl)glucose (Group II), $\left[{ }^{14} \mathrm{C}\right]$-Soluble Residues (Group III), $\left[{ }^{14} \mathrm{C}\right]$-Bound Residues (Group IV), and [ $\left.{ }^{14} \mathrm{C}\right]-\mathrm{Total}$ Residues (Group V)

\begin{tabular}{|c|c|c|c|c|c|}
\hline & \multicolumn{5}{|c|}{ distribution of radioactivity ( $\%$ dose) } \\
\hline & {$\left[{ }^{14} \mathrm{C}\right]-\mathrm{DCP}$} & DCP-(acetyl)glucose & soluble residues & bound residues & total residues \\
\hline urine $0-24 \mathrm{~h}$ & $66.2 \pm 1.2$ & $83.5 \pm 4.1$ & $59.9 \pm 13.9$ & $0.5 \pm 0.03$ & $25.8 \pm 2.0$ \\
\hline urine $24-48 \mathrm{~h}$ & $3.0 \pm 0.1$ & $2.2 \pm 0.3$ & $9.2 \pm 1.8$ & $0.2 \pm 0.07$ & $3.1 \pm 1.8$ \\
\hline urine $0-48 \mathrm{~h}$ & $69.2 \pm 12.7$ & $85.7 \pm 4.2$ & $69.2 \pm 15.4$ & $0.70 \pm 0.07$ & $28.9 \pm 2.0$ \\
\hline feces $0-24 \mathrm{~h}$ & $1.8 \pm 0.8$ & $6.4 \pm 0.6$ & $4.6 \pm 0.7$ & $42.7 \pm 18.2$ & $20.4 \pm 9.2$ \\
\hline feces $24-48 \mathrm{~h}$ & $1.7 \pm 0.1$ & $0.4 \pm 0.1$ & $5.1 \pm 1.6$ & $47.1 \pm 15.66$ & $24.0 \pm 5.6$ \\
\hline feces $0-48 \mathrm{~h}$ & $3.5 \pm 0.9$ & $6.8 \pm 0.7$ & $9.7 \pm 1.1$ & $89.8 \pm 2.7$ & $44.4 \pm 3.6$ \\
\hline liver & $0.04 \pm 0.01$ & $0.002 \pm 0.000$ & $0.10 \pm 0.01$ & $0.010 \pm 0.002$ & $0.07 \pm 0.01$ \\
\hline kidney & $0.01 \pm 0.00$ & $0.001 \pm 0.000$ & $0.02 \pm 0.00$ & $0.001 \pm 0.000$ & $0.020 \pm 0.002$ \\
\hline total & $73.2 \pm 15.2$ & $92.5 \pm 3.9$ & $78.9 \pm 14.4$ & $90.6 \pm 2.7$ & $73.4 \pm 4.7$ \\
\hline
\end{tabular}

short half-life in these organs $(\leq 30 \mathrm{~min})$ of DCP and corresponding conjugates observed in rats treated with a single intravenous administration of DCP. ${ }^{18}$ DCP and plant residues were rapidly distributed but did not accumulate into tissues of rats. In addition, all compounds were removed from the liver (Table 2). Due to the absence of bioaccumulation, DCP represents a weaker long-term toxicological risk than other persistent organic pollutants (POPs). POPs are readily absorbed but very slowly eliminated from tissues and concentrate in living organisms through bioaccumulation. For example, organochlorine pesticides mainly accumulate in the fatty tissue of animals ${ }^{25,26}$ except chlordecone, which exhibits the highest concentration in the liver. ${ }^{27}$ However, plant conjugates of DCP represent a sink for DCP as conjugates are cleaved to give the toxic parent compound again after absorption in the gastrointestinal tract of animals. They are thereafter conjugated to sulfate or glucuronic acid in liver prior to elimination in urine.
Through contaminated food, living organisms will thus be exposed to the parent compound, which causes toxicity.

Radioactivity associated with unextractable residues was completely recovered in feces within $48 \mathrm{~h}$. DCP bound residues do not seem to be absorbed by the rat because almost no radioactivity was detected in urine. This result is in agreement with the general finding that bound residues are known to be hardly bioavailable. However, some studies with pesticide bound residues evidenced significant bioavailability rates. ${ }^{28}$ These contrasting situations can be partly explained by different preparation protocols of plant extracts, different fractionation procedures of cell walls, physicochemical properties of chemicals, and digestibility of the macromolecule to which the pesticide is bound. ${ }^{29}$ The fate of bound residues in animals is thus difficult to estimate or extrapolate and generally requires specific studies for each molecule.

Total residues were excreted both in urine and in feces. This result was expected as residues consisted in the sum of soluble 


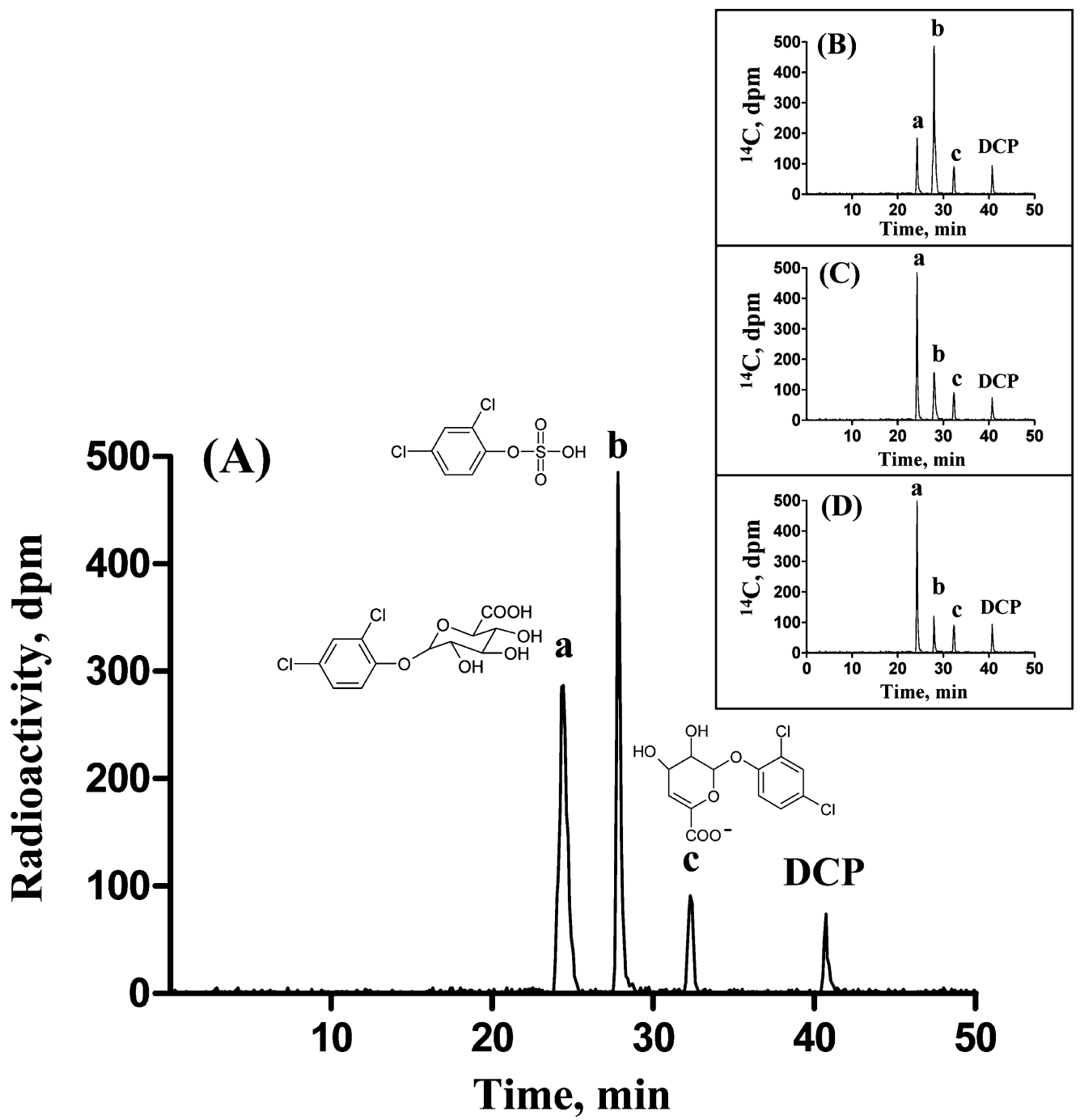

Figure 2. Typical radio-HPLC profiles for $0-24 \mathrm{~h}$ urine collected from rats treated with $(\mathrm{A})\left[{ }^{14} \mathrm{C}\right]-\mathrm{DCP},(\mathrm{B})\left[{ }^{14} \mathrm{C}\right]-\mathrm{DCP}-($ acetyl $)$ glucose, $(\mathrm{C})\left[{ }^{14} \mathrm{C}\right]$ soluble residues, and (D) $\left[{ }^{14} \mathrm{C}\right]$-total residues.

and bound residues. However, the obtained percentages represented 29 and $44 \%$ of the administered dose or 40 and $60 \%$ of the excreted total dose, respectively. After $\left[{ }^{14} \mathrm{C}\right]$-DCP uptake by radish plants, distribution of radioactivity between solventextractable and unextractable residues showed that a large proportion was soluble $(24.9 \%$, or $19.0 \mu$ g equiv parent compound $\mathrm{g}^{-1} \mathrm{DW}$, and $16.9 \%$, or $12.2 \mu \mathrm{g}$ equiv parent compound $\mathrm{g}^{-1} \mathrm{DW}$ of the applied radioactivity for $\left[{ }^{14} \mathrm{C}\right]-\mathrm{DCP}$, respectively). ${ }^{10}$ Soluble residues accounted for $60 \%$ and unextractable residues for $40 \%$ of the radioactivity taken up by radish plants. This meant that soluble residues are less easily absorbed in comparison with the major soluble metabolite purified from plant cells. Studies investigating food matrix influence have already been reported for some flavonoid subclasses, ubiquitous polyphenolic compounds throughout the plant kingdom. ${ }^{30}$

Urinary Metabolite Identification. $M S$ and NMR Identification of DCP Metabolites. A typical radio-HPLC chromatogram obtained from urine of rats treated with $\left[{ }^{14} \mathrm{C}\right]$ DCP (group I) is shown in Figure 2A. Three peaks, two major and one minor, were detected in addition to unchanged DCP. Peaks were further identified by mass spectrometry. Mass spectrometry data of urinary DCP metabolites are gathered in Table 1.
The chemical structure of peak a was identified as the glucuronide conjugate of DCP. This result is in accordance with the data obtained by Somani and Khalique ${ }^{18}$ in rats after intravenous administration of unlabeled DCP $\left(10 \mathrm{mg} \mathrm{kg}^{-1}\right)$. These authors reported that DCP metabolites found in plasma, liver, and kidney were predominantly DCP conjugates, the DCP-glucuronide being the major residue. The conjugation of DCP with glucuronic acid was also identified as the principal metabolic pathway of DCP by isolated perfused rat liver. ${ }^{31}$ Two other metabolites were isolated from the perfusate and identified by GC-MS as dichloromethoxyphenols. Under our experimental conditions, no trace of these biotransformation products was detected in urine.

Peak $b$ was identified as the sulfate conjugate of DCP, on the basis of the characteristic loss of $\mathrm{SO}_{3}$ observed by MS/MS (Table 1). However, this metabolite has not been previously evidenced in rats. ${ }^{18,31}$ DCP may also be excreted as a sulfate conjugate in urine of rabbits. ${ }^{32}$

For peak c, MS data were consistent with a structure corresponding to DCP conjugated to a dehydrated glucuronide. Indeed, the full MS spectrum (Figure 3A) obtained from peak c displays a characteristic isotopic pattern of an ion holding two chloride atoms at $m / z 319$. The resulting MS/MS spectrum of the $m / z 319$ precursor ion is shown in Figure 3B and displays 

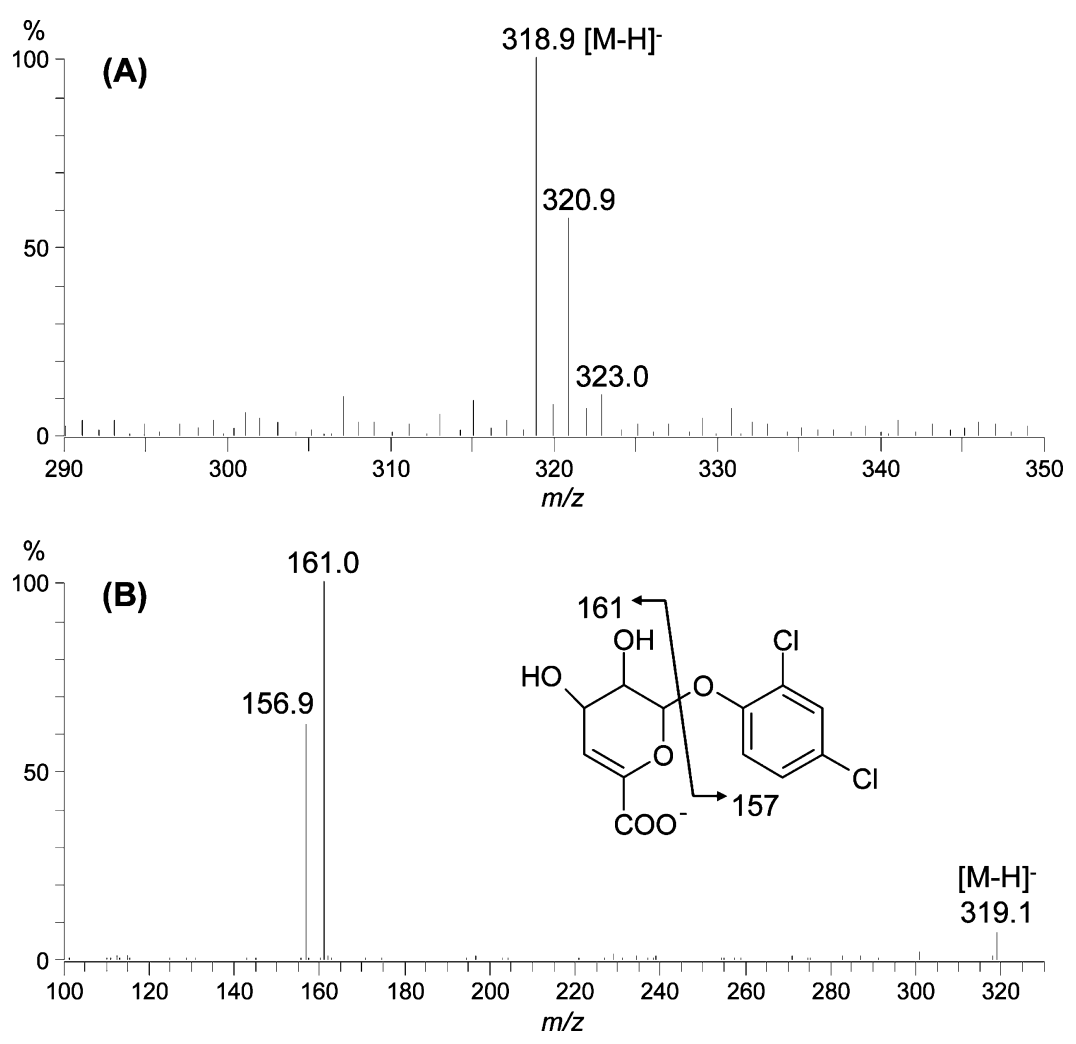

Figure 3. (A) Full MS spectrum and (B) full MS/MS spectrum of the $m / z 319$ precursor ion, obtained with ESI operating in the negative mode, of the dehydrated glucuronide metabolite $(\mathrm{c})$ isolated from $0-24 \mathrm{~h}$ urine collected from rats treated with either $\left[{ }^{14} \mathrm{C}\right]-\mathrm{DCP}$, $\left[{ }^{14} \mathrm{C}\right]$-soluble residues, $\left[{ }^{14} \mathrm{C}\right]$-total residues, or $\left[{ }^{14} \mathrm{C}\right]$-DCP-(acetyl)glucose.

two complementary fragment ions. The $m / z 161$ ion corresponds to DCP, which was confirmed by MS/MS of the $m / z$ 321 ion (Table 1). The second fragment ion observed in Figure $3 \mathrm{~B}$ at $\mathrm{m} / \mathrm{z} 157$ corresponds to a dehydrated glucuronide moiety in accordance with a possible DCP conjugated with a dehydrated glucuronic acid. To confirm this structure, this metabolite was analyzed by ${ }^{1} \mathrm{H}$ and $2 \mathrm{D}$ NMR, including ${ }^{1} \mathrm{H}-{ }^{1} \mathrm{H}$ gs-COSY, ${ }^{1} \mathrm{H}-{ }^{13} \mathrm{C}$ gs-HSQC, and ${ }^{1} \mathrm{H}-{ }^{13} \mathrm{C}$ gs-HMBC. The ${ }^{1} \mathrm{H}$ NMR spectrum displayed characteristic signals (Figure 4 and Table 3). In the aromatic region, the signals belonging to the DCP moiety are clearly identified (two doublets at 7.45 and $7.37 \mathrm{ppm}$ and a double doublet at $7.29 \mathrm{ppm}$ ). In the sugar region, two doublets (6.24 and $5.76 \mathrm{ppm})$ and two triplets (4.05 and $4.14 \mathrm{ppm}$ ) were observed. The 2D COSY NMR spectrum showed correlations between the signals at $5.67 \mathrm{ppm}$ $\left(\mathrm{H}-\mathrm{1}^{\prime}\right)$ and $4.05 \mathrm{ppm}\left(\mathrm{H}-2^{\prime}\right)$, between the signals at $4.05 \mathrm{ppm}$ $\left(\mathrm{H}-2^{\prime}\right)$ and $4.14 \mathrm{ppm}\left(\mathrm{H}-3^{\prime}\right)$, and between the signals at $4.14 \mathrm{ppm}\left(\mathrm{H}-3^{\prime}\right)$ and $6.24 \mathrm{ppm}\left(\mathrm{H}-4^{\prime}\right)$. Consequently, these protons belonged to the same spin system. ${ }^{13} \mathrm{C}$ chemical shifts have been determined using 2D HSQC and HMBC NMR spectra. A ${ }^{1} \mathrm{H}$ chemical shift of $6.24 \mathrm{ppm}$ and ${ }^{13} \mathrm{C}$ chemical shifts $(\delta 113.5$ and 145.8) confirmed the presence of a double bond in the sugar moiety with a quaternary carbon, and the ${ }^{13} \mathrm{C}$ chemical shift of 169.5 ppm confirmed the presence of a carbonyl group. Furthermore, long-range correlations in the HMBC NMR spectrum showed that the double bond is at position 4'5'. Indeed, $\mathrm{HMBC}$ correlations between the ${ }^{1} \mathrm{H}$ signal at $6.24 \mathrm{ppm}\left(\mathrm{H}-4^{\prime}\right)$ ascribed to olefinic proton and the ${ }^{13} \mathrm{C}$ signal at 169.5 ppm (C-6') ascribed to the carbonyl group evidenced that the double bond is at position $4^{\prime}-5^{\prime}$. Correlations between the ${ }^{1} \mathrm{H}$ signal at $6.24 \mathrm{ppm}\left(\mathrm{H}-4^{\prime}\right)$ and the ${ }^{13} \mathrm{C}$ signals at $145.8 \mathrm{ppm}$ $\left(\mathrm{C}-5^{\prime}\right), 67.1 \mathrm{ppm}\left(\mathrm{C}-3^{\prime}\right)$, and $70.8 \mathrm{ppm}\left(\mathrm{C}-2^{\prime}\right)$ confirmed the

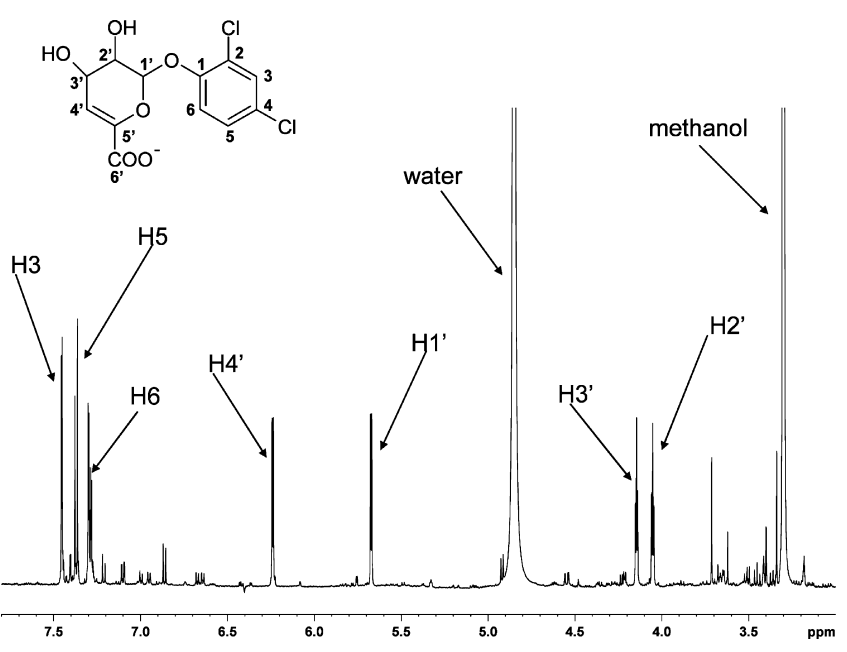

Figure 4. $600 \mathrm{MHz}{ }^{1} \mathrm{H}$ NMR spectrum in $\mathrm{CD}_{3} \mathrm{OD}$ of the dehydrated glucuronide metabolite $(\mathrm{c})$ isolated from $0-24 \mathrm{~h}$ urine collected from rats treated with either $\left[{ }^{14} \mathrm{C}\right]-\mathrm{DCP},\left[{ }^{14} \mathrm{C}\right]$-DCP-(acetyl)glucose, $\left[{ }^{14} \mathrm{C}\right]$ soluble residues, or $\left[{ }^{14} \mathrm{C}\right]$-total residues.

chemical structure of this metabolite. The latter has been seldom described in the metabolism of xenobiotics in animals or microorganisms. Zalko et al. ${ }^{33}$ have reported the characterization of a dehydrated glucuronide conjugate in the metabolism of bisphenol A (2,2-bis(4-hydroxyphenyl)propane) in CD1 mice. We cannot rule out the possibility that the elimination of a water molecule took place after the conjugation of glucuronic acid with DCP as a degradation product even if the cleavage of the ether-linked glucuronide bond is thermodynamically more favorable. 
Table $3 .{ }^{13} \mathrm{C}$ and ${ }^{1} \mathrm{H}$ Chemical Shifts of DCP-Dehydrated Glucuronide in $\mathrm{CD}_{3} \mathrm{OD}^{a}$

\begin{tabular}{ccc} 
atom & $\delta^{13} \mathrm{C}$ & \multicolumn{1}{c}{$\delta^{1} \mathrm{H}$} \\
1 & 152.1 & \\
2 & 121.8 & $7.45(\mathrm{~d}) ; J=2.4 \mathrm{~Hz}$ \\
3 & 130.4 & \\
4 & 126.1 & $7.29(\mathrm{dd}) ; J=9,2.4 \mathrm{~Hz}$ \\
5 & 120.5 & $7.37(\mathrm{~d}) ; J=9 \mathrm{~Hz}$ \\
6 & 128.5 & $5.67(\mathrm{~d}) ; J=4.3 \mathrm{~Hz}$ \\
$1^{\prime}$ & 100.3 & $4.05(\mathrm{t}) ; J=4.3 \mathrm{~Hz}$ \\
$2^{\prime}$ & 70.8 & $4.14(\mathrm{t}) ; J=4.3 \mathrm{~Hz}$ \\
$3^{\prime}$ & 67.1 & $6.24(\mathrm{~d}) ; J=4.3 \mathrm{~Hz}$ \\
$4^{\prime}$ & 113.5 & \\
$5^{\prime}$ & 145.8 & \\
$6^{\prime}$ & 169.5 &
\end{tabular}

${ }^{a}$ Chemical shifts are relative to $\mathrm{CD}_{3} \mathrm{OD}\left({ }^{1} \mathrm{H} \delta 3.31\right.$ and $4.87 ;{ }^{13} \mathrm{C} \delta$ 49.0). Multiplicity of signals is indicated: $d$, doublet; $t$, triplet; $d d$, double doublet.

Identification of Metabolites of DCP-(acetyl)glucose, Soluble, and Total Residues. Typical profiles obtained from urine of rats treated with DCP-(acetyl)glucose (group II) were similar to those of rats treated with the parent compound (Figure 2B, inset). HPLC profiles obtained from urine of rats treated with soluble and total residues (groups III and V) were qualitatively but not quantitatively similar to those of rats treated with DCP or DCP-(acetyl)glucose (Figure 2C,2D, inset). Plant DCP metabolites administered to rats (groups II, III, and $\mathrm{V})$ were undetectable in urine samples under our conditions, and this was confirmed by MS (Table 1). As for treatment of rats with DCP, the metabolites identified in urine from groups II, III, and V were DCP-glucuronide, DCP-sulfate, and DCPdehydrated glucuronide.

An HPLC profile could not be established after bound residue administration (group IV) due to the very small amount of radioactivity in urine.

Comparison of the Amounts of Urine Metabolites. Quantities (nmol day ${ }^{-1}$ ) of each metabolite excreted in the urine, including unchanged parent compound, are reported for groups I, II, III, and V in Figure 5. Metabolic profiles from DCP and DCP-(acetyl)glucose were very close (Figure 5A). No significant differences were observed between amounts of excreted glucuronide or sulfate compounds, but an interindividual variability was observed. Conjugation to sulfate or glucuronic acid seemed to occur indiscriminately. These results indicate that DCP-(acetyl)glucose, as well as DCP, is readily absorbed from the gastrointestinal tract of rats. Glucosides are generally hydrolyzed by microflora in the intestines of mammals, ${ }^{21}$ but, sometimes, ether-linked glucosides were eliminated mostly or partly unchanged in urine. ${ }^{34}$ Several studies evidenced that the fate of xenobiotic glucosides in rat is structure-dependent. The metabolism of the ester glucoside of 3-phenoxybenzoic acid was similar to that of 3-phenoxybenzoic acid, leading to an elimination as a sulfate conjugate. ${ }^{35}$ The elimination of the malonyl glucoside conjugate of phenol was similar to that of phenol, whereas phenol glucoside was eliminated mainly unchanged. ${ }^{36}$ Plant secondary metabolites occur in a variety of conjugated forms, and the structure of the sugar moiety plays a crucial role in their absorption, for example, of dietary quercetin, an antioxidant flavonoid. Quercetin glucosides were absorbed from the small intestine, whereas the rutinoside
(A)

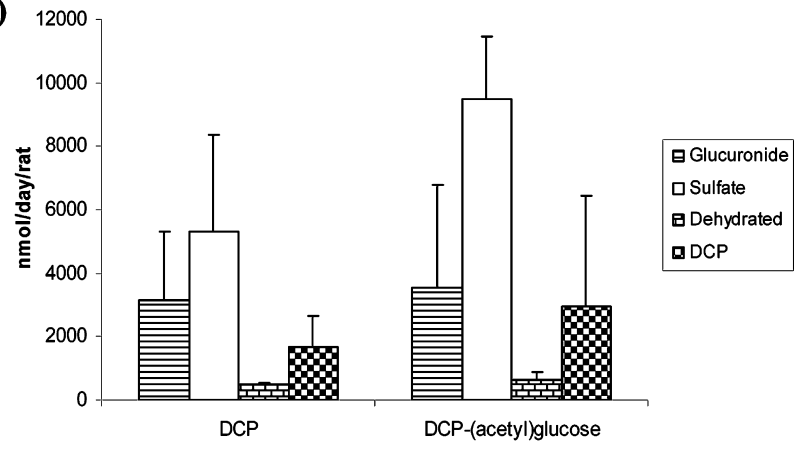

(B)

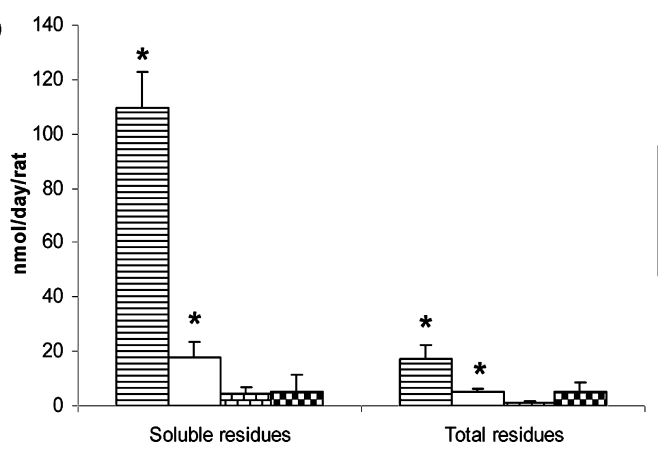

Figure 5. Amounts of metabolites in urine of rats following administration of (A) $\left[{ }^{14} \mathrm{C}\right]$-DCP and $\left[{ }^{14} \mathrm{C}\right]$-DCP-(acetyl)glucose and $(\mathrm{B})\left[{ }^{14} \mathrm{C}\right]$-soluble residues and $\left[{ }^{14} \mathrm{C}\right]$-total residues.

(rhamnose-glucose) form was absorbed from the colon after deglycosylation in humans. ${ }^{37}$

In contrast to DCP- and DCP-(acetyl)glucose-treated rats, for which urinary metabolites were predominantly sulfate conjugates, both soluble and total residues groups showed mainly DCP-glucuronide in urine (Figure 5B). However, as previously discussed, the doses administered to these groups were substantially different. Soluble residues were composed of DCP(acetyl)glucose, which represented $75 \%$ of the total extractable residues (TER), DCP-glucose (10\% of TER), and unidentified peaks (15\% TER). ${ }^{10}$ Because soluble residues, administered directly or included in the vegetal matrix, were mainly composed of DCP-(acetyl)glucose (Figure 1A), we expected similar urinary metabolic profiles from groups II and III. The discrepancy could be due to the saturation of sulfotransferases or their cofactors by endogenous secondary metabolites of plants, for example, anthocyanins, the most important group of water-soluble pigments in plants. Anthocyanins provide the red color to radish plants and belong to the flavonoid class, which are generally found in the form of glycosides. ${ }^{38}$ Indeed, glucuronidation is a very high capacity system of detoxification because the cofactor, uridine diphosphate glucuronic acid (UDPGA), is always available, whereas the cofactor of sulfatases, 3'phosphoadenosine-5'-phosphosulfate (PAPS), can sometimes be limited. $^{34}$

This study clearly demonstrates that the soluble fraction of DCP residues present in plants is bioavailable in mammals, whereas bound residues are not absorbed. Plant DCP conjugates are likely to contribute substantially to the exposure of the general population to DCP. This observation may be probably expanded to several categories of chemicals, including pesticides. Accordingly, our data suggest that extractable residues should then be taken into account in occurrence data regarding residues of pesticide treatment in plants. Although some 
quantitative differences were observed between rats treated with the soluble fraction (or total residues) and rats receiving the pure compounds (DCP or DCP-(acetyl)glucose), similar metabolic pathways were found in these groups. In particular, no trace of dichloromethoxyphenols, which have been found in vitro ${ }^{32}$ and which are suspected to be indicative of a biologically reactive metabolite such as an epoxide intermediate, were found in our study.

In conclusion, the present work focused on the comparison of oral administration to rats of DCP with plant residues, DCP(acetyl)glucose, soluble, total, and bound residues from radish plants. DCP was rapidly absorbed and eliminated in urine equally in the form of sulfate and glucuronide conjugates. A new metabolite was also detected and characterized as a dehydrated glucuronide conjugate of DCP. DCP-(acetyl)glucose exhibited a urinary metabolic profile similar to that of DCP. Plant conjugates of DCP were absorbed in the digestive tract of rats, and the major part was eliminated in urine subsequent to biotransformation in sulfate and glucuronide conjugates. Living organisms are thus exposed to DCP through the food chain. The vegetal matrix seemed to influence the metabolic profiles derived from soluble and total residues as urinary elimination proceeded predominantly through glucuronidation. In addition, a plant matrix effect was also evidenced because the behavior of total residues was different (less absorption occurred) from that expected from soluble and bound residues. Bound residues seemed to be unabsorbed under our conditions and consequently should be not bioavailable and of limited toxicological concern.

\section{AUTHOR INFORMATION}

\section{Corresponding Author}

*Postal address: INRA - USC 5245 EcoLab, 180 Chemin de Tournefeuille, Bâtiment A, B.P. 93173, 31027 Toulouse Cedex 3, France. E-mail: Sophie.Pascal@toulouse.inra.fr. Phone: +33 561.28.53.92. Fax: +33 561.28.52.44.

\section{Notes}

The authors declare no competing financial interest.

\section{ACKNOWLEDGMENTS}

We thank R. Gazel and F. Blas-Y-Estrada for excellent technical support. We thank Dr. N. Cabaton (INRA, UMR Toxalim, Toulouse, France) for correcting the English.

\section{ABBREVIATIONS USED}

COSY, correlation spectroscopy; DCP, 2,4-dichlorophenol; DW, dry weight; equiv, equivalent; ESI-MS, electrospray ionizationmass spectrometry; gs-HMBC, gradient-selected heteronuclear multiple-bond connectivity; gs-HMQC, gradient-selected heteronuclear single-quantum correlation; LC-MS, liquid chromatography-mass spectrometry; NMR, nuclear magnetic resonance; RP-HPLC, reverse-phase high-performance liquid chromatography; $t_{R}$, retention time; TER, total extractable residues.

\section{REFERENCES}

(1) Crespin, M. A.; Gallego, M.; Valcarcel, M. Study of the degradation of the herbicides 2,4-D and MCPA at different depths in contaminated agricultural soil. Environ. Sci. Technol. 2001, 35, 42654270 .

(2) Abdel-Gawad, H.; Afifi, L. M.; Abdel-Hameed, R. M.; Hegazi, B. Distribution and degradation of ${ }^{14} \mathrm{C}$-ethyl prothiofos in a potato plant and the effect of processing. Phosphorus, Sulfur, Silicon 2008, 183, 2734-2751.
(3) Escher, B. I.; Schwarzenbach, R. P. Partitioning of substituted phenols in liposome-water, biomembrane-water, and octanol-water systems. Environ. Sci. Technol. 1995, 30, 260-270.

(4) IARC (International Agency for Research on Cancer). Polychlorophenols and their sodium salts. In Re-evaluation of Some Organic Chemicals, Hydrazine and Hydrogen Peroxide; IARC Monographs on the Evaluation of Carcinogenic Risks to Humans; World Health Organization: Lyon, France, 1999; Vol. 71, pp 769-816 (available at http://monographs.iarc.fr/ENG/Monographs/vol71/ index.php).

(5) ATSDR (Agency for Toxic Substances and Disease Registry). Toxicological Profile for Chlorophenols; U.S. Department of Health and Human Services; Public Health Service: Atlanta, GA, 1999 (available at http://www.atsdr.cdc.gov/ToxProfiles/tp107.pdf).

(6) Laurent, F. L.; Debrauwer, L.; Pascal-Lorber, S. Metabolism of $\left[{ }^{14} \mathrm{C}\right]$-2,4-dichlorophenol in edible plants. Pest Manag. Sci. 2006, 62, $558-564$.

(7) Thomson, C. A.; Chesney, D. J. Supercritical carbon dioxide extraction of 2,4-dichlorophenol from food crop tissues. Anal. Chem. 1992, 64, 848-853.

(8) Rodrigues, D.; Carvalho, T.; Sousa, A.; Sousa Neto, V.; Fechine, P.; Nascimento, R. Determination of insecticide residues in vegetal fruits. Chromatogr. Res. Int. 2011, article ID 713256, DOI: 10.4061/ 2011/713256.

(9) Wright, T. R.; Shan, G.; Walsh, T. A.; Lira, J. M.; Cui, C.; Song, P.; Zhuang, M.; Arnold, N. L.; Lin, G.; Yau, K.; Russell, S. M.; Cicchillo, R. M.; Peterson, M. A.; Simpson, D. M.; Zhou, N.; Ponsamuel, J.; Zhang, Z. Robust crop resistance to broadleaf and grass herbicides provided by aryloxyalkanoate dioxygenase transgenes. Proc. Natl. Acad. Sci. U.S.A. 2010, 107, 20240-20245.

(10) Pascal-Lorber, S.; Despoux, S.; Rathahao, E.; Canlet, C.; Debrauwer, L; Laurent, F. Metabolic fate of chlorophenols in radish (Raphanus sativus), lettuce (Lactuca sativa), and spinach (Spinacia oleracea). J. Agric. Food Chem. 2008, 56, 8461-8469.

(11) Bockern, M.; Nimtz, M.; Harms, H. H. Metabolites of 4-nnonylphenol in wheat cell suspension cultures. J. Agric. Food Chem. 1996, 44, 1123-1127.

(12) Laurent, F.; Canlet, C.; Debrauwer, L.; Pascal-Lorber, S. Metabolic fate of $\left[{ }^{14} \mathrm{C}\right]-2,4$-dichlorophenol in tobacco cell suspension cultures. Environ. Toxicol. Chem. 2007, 26, 2299-2307.

(13) Lamoureux, G. L. Plant metabolism of herbicides in relation to detoxification, selectivity, antidoting, and synergism. In Xenobiotic Metabolism and Disposition; Kato, R., Eastabrook, R. W., Gayen, M. N., Eds.; Taylor and Francis: Bristol, PA, 1989; pp 267-274.

(14) Capps, T. M.; Barringer, V. M.; Eberle, W. J.; Brown, D. R.; Sanson, D. R. Identification of a unique glucosylsulfate conjugate metabolite of profenofos in cotton. J. Agric. Food Chem. 1996, 44, $2408-2411$.

(15) Laurent, F.; Debrauwer, L.; Rathahao, E.; Scalla, R. 2,4Dichlorophenoxyacetic acid metabolism in transgenic tolerant cotton (Gossypium hirsutum). J. Agric. Food Chem. 2000, 48, 5307-5311.

(16) Pascal-Lorber, S.; Rathahao, E.; Cravedi, J.-C.; Laurent, F. Uptake and metabolic fate of $\left[{ }^{14} \mathrm{C}\right]-2,4-$ dichlorophenol and $\left[{ }^{14} \mathrm{C}\right]-2,4-$ dichloroaniline in wheat (Triticum aestivum) and soybean (Glycine max). J. Agric. Food Chem. 2003, 51, 4712-4718.

(17) Day, J. A.; Saunders, F. M. Glycosidation of chlorophenols by Lemna minor. Environ. Toxicol. Chem. 2004, 23, 613-620.

(18) Somani, S. M.; Khalique, A. Distribution and metabolism of 2,4dichlorophenol in rats. J. Toxicol. Environ. Health 1982, 9, 889-897.

(19) Hollman, P. C. H.; van Trijp, J. M. P.; Buysman, M. N. C. P.; v.d. Gaag, M. S.; Mengelers, M. J. B.; de Vries, J. H. M.; Katan, M. B. Relative bioavailability of the antioxidant flavonoid quercetin from various foods in man. FEBS Lett. 1997, 418, 152-156.

(20) Viskupičová, J.; Ondrejovič, M.; Šturdík, E. Bioavailability and metabolim of flavonoids. J. Food Nutr. Res. 2008, 47, 151-162.

(21) Skidmore, M. W.; Benner, J. P.; Lam, C. C. C.; Booth, J. D.; Clark, T.; Gledhill, A. J.; Roberts, K. J. Bioavailability of common conjugates and bound residues. In Pesticide Chemistry. Crop Protection, 
Public Health, Environmental Safety; Ohkawa, H., Miyagawa, H., Lee, P. W., Eds.; Wiley: Weinheim, Germany, 2007; pp 383-393.

(22) Schmidt, B. Non-extractable residues of pesticides and xenobiotics in plants - a review. Recent Res. Dev. Agric. Food Chem. 1999, 3, 329-354.

(23) Laurent, F. M. G.; Scalla, R. Metabolism and cell wall incorporation of phenoxyacetic acid in soybean cell suspension culture. Pestic. Sci. 1999, 55, 3-10.

(24) Langebartels, C.; Harms, H. Analysis for nonextractable (bound) residues of pentachlorophenol in plant cells using a cell wall fractionation procedure. Ecotoxicol. Environ. Saf. 1985, 10, 268279.

(25) Müllerová, D.; Kopecký, J. White adipose tissue: storage and effector site for environmental pollutants. Physiol. Res. 2007, 56, 375381.

(26) El-Shahawi, M. S.; Hamza, A.; Bashammakh, A. S.; Al-Saggaf, W. T. An overview on the accumulation, distribution, transformations, toxicity and analytical methods for the monitoring of persistent organic pollutants. Talanta 2010, 80, 1587-1597.

(27) Linder, R. E.; Scotti, T. M.; McElroy, W. K.; Laskey, J. W.; Strader, L. F.; Powell, K. Spermotoxicity and tissue accumulation of chlordecone (Kepone) in male rats. J. Agric. Food Chem. 1983, 12, 183-192.

(28) Kacew, S.; Akhtar, M. H.; Khan, S. U. Bioavailability of bound pesticide residues and potential toxicologic consequences - an update. Proc. Soc. Exp. Biol. Med. 1996, 211, 62-68.

(29) Sandermann, H. Jr. Bound and unextractable pesticidal plant residues: chemical characterization and consumer exposure. Pest Manag. Sci. 2004, 60, 613-623.

(30) Schramm, D. D.; Karim, M.; Schrader, H. R.; Holt, R. R.; Kirkpatrick, N. J.; Polagruto, J. A.; Ensunsa, J. L.; Schmitz, H. H.; Keen, C. L. Food effects on the absorption and pharmacokinetics of cocoa flavanols. Life Sci. 2003, 73, 857-869.

(31) Somani, S. M.; Smart, T.; Khalique, A. Metabolism of 2,4dichlorophenol by isolated perfused rat liver. J. Toxicol. Environ. Health 1984, 13, 787-798.

(32) NRC (National Research Council). Organic solutes. In Drinking Water \& Health; National Academy Press: Washington, DC, 1977; Vol. 1, pp 725-726.

(33) Zalko, D.; Soto, A. M.; Dolo, L.; Dorio, C.; Rathahao, E.; Debrauwer, L.; Faure, R.; Cravedi, J.-P. Biotransformations of bisphenol $\mathrm{A}$ in a mammalian model: answers and new questions raised by low-dose metabolic fate studies in pregnant CD1 mice. Environ. Health Perspect. 2003, 111, 309-319.

(34) Bounds, S. V. J.; Hutson, R. The comparative metabolism of agrochemicals in plants and mammals. In Metabolism of Agrochemicals in Plants; Roberts, T., Ed.; Wiley: Chichester, U.K., 2000; pp 179-209. (35) Crayford, J. V.; Hutson, D. H. The metabolism of 3phenoxybenzoic acid and its glucoside conjugate in rats. Xenobiotica 1980, 10, 355-364.

(36) Edwards, V. T.; Jones, B. C.; Hutson, D. H. A comparison of the metabolic fate of phenol, phenyl glucoside and phenyl 6-O-malonylglucoside in the rat. Xenobiotica 1986, 16, 801-807.

(37) Karakaya, S. Bioavailability of phenolic compounds. Crit. Rev. Food Sci. Nutr. 2004, 44, 453-464.

(38) Felgines, C.; Talavera, S.; Gonthier, M. P.; Texier, O.; Scalbert, A.; Lamaison, J. L.; Remesy, C. Strawberry anthocyanins are recovered in urine as glucuro- and sulfoconjugates in humans. J. Nutr. 2003, 133, $1296-1301$. 